\title{
Omsorgsorgsarbetet i brytningen mellan privat och offentligt
}

\section{INGA MICHAELI}

Välfärdsstaten med dess omsorg i offentlig regi, har medfört att gränsen mellan privat och offentligt har luckrats upp. Motstridiga krav på empati och distans, på omsorg och rättvis a riktas $i$ dag mot personal i vård och omsorg. Inom moralfilosofin diskuteras former för att hantera dessa motsättningar. I artikeln diskuteras två konkreta rättsfall $i$ relation till en sådan moralfilosofisk modell. Syftet är att ge ett bidrag till en omsorgspolitisk diskussion. Ytterst handlar den om tänkbara nya organisatoriska och arbetsrättsliga former som välfärdsstatens förändring tvingar fram.

I slutet av 1980-talet åtalades två hemvårdsbiträden för mutbrott. I det ena fallet hade vårdtagaren skänkt sin gård till vårdbiträdet mot det att vårdbiträdet och hennes make skulle flytta till gården och ta hand om henne. Det andra fallet gällde en gammal man som uppfattade vårdbiträdet som sin käresta, fick godnattpussar av henne och hade flera gånger gett henne pengar som hon tagit emot. I det första fallet frikändes vårdbi-

Inga Michaeli är fil.dr och har disputerat vid tidigare Nordiska Institutet för samhällsplanering i Stockholm med inritning mot sociala frågor. Hon är nu knuten till Högskolan i Gävle. trädet med hänvisning till att de två parterna kände varandra sedan tidigare. Det var alltså som privatpersoner, som grannar, de ingått en överenskommelse. I det andra fallet blir vårdbiträdet fällt för tagande av muta. Vårdaren och vårdtagaren kände inte varandra sedan tidigare. Det var alltså såsom tjänsteman hon tagit emot pengarna.

Båda fallen avspeglar en motsättning mellan förhållningssätt knutna till privat och offentligt. Kärlek, vänskap och empati, en kvalitet i det privata och i omsorgsverksamhet, konfronteras med idealet om den neutrale, omutlige tjänstemannen. Problemen ligger där ofrånkomliga. Har vårdbiträ- 
dena lurat av sina klienter gård respektive pengar i kraft av sin position som kommunanställda vårdare med makt över dem de vårdar. Eller är gåvorna uttryck för vårdtagarens behov att bekräfta en relation och som vårdbiträdet av hänsyn till sin klient inte vill avvisa. De två fallen illustrerar frågor som är aktuella och påträngande för de flesta som arbetar inom vård och omsorg i dag. De kan knytas till en moralfilosofisk debatt som har pågått under 1980-90-talet och som ibland beskrivs i termer av "rättvisemoral" kontra "omsorgsmoral".

I dag ser vi nya former av vård och omsorg utvecklas, som på olika sätt berör gränsen mellan privat och offentligt. Äldreomsorgens resurser har minskat successivt sedan början på 80-talet (Szebehely 1993). Vårdtiderna kortas och patienter ska i större utsträckning skötas i hemmet. Troligt är att mer omsorgsarbete görs som informellt obetalt arbete i dag än i början av 80-talet (Johansson 1997). Experter från det offentliga, distriktssköterskor, vårdbiträden m.m., tar plats i det privatas kärna - hemmet. Frivilligorganisationer uppmuntras. Vård och omsorg läggs ut på anbud till privata företag, vilket i sin tur kräver någon form av tillsyn från det offentligas sida. Alla dessa förändringar omvandlar och luckrar upp gränsen privat/offentligt. I viss mening förs omsorgen tillbaks till det privata, till hemmet eller till privata marknaden. Men samtidigt finns det offentligas representanter närvarande, som stöd och expertkunskap eller som tillsynsmyndighet.

En moralfilosofi och rättsliga bedömningar som bygger på en strikt uppdelning $\mathrm{i}$ offentligt och privat i dess gamla former ger därför problem. I artikeln vill jag genom de två rättsfallen belysa några av dessa. Vidare vill jag ta upp en moralfilosofisk position föreslagen av Sheila Benhabib som syftar till att överskrida den motsättning mellan de förhållningssätt som privat och offentligt står för i dag. De två rättsfallen använder jag för att göra den konkreta innebörden i hennes position synlig. En följd av Benhabibs resonemang är bl.a. att omsorgsarbetet måste kunna bli mer offentligt, i meningen att överväganden inom omsorgsarbetet måste kunna föras upp i en offentlig diskussion.

Artikelns syfte är att ge ett bidrag till en omsorgspolitisk diskussion om hur brytningen privat-offentligt kan hanteras, där frågan om omsorgsarbetets »osynlighet« är central.

\section{Två rättsfall}

I slutet på 1980-talet åtalades två hemvårdare $^{1)}$ för mutbrott under $2 \S$ i brottsbalkens 20:e kapitel »om myndighetsmissbruk». (Numera heter kapitlet "Om tiänstefel m.m.»). Det ena fallet gällde vårdbiträdet Karin, som i flera år tittat till sina grannar, ett gammalt syskonpar Edvin och Emmy, hjälpt och stöttat dem. När brodern i granngården dör och Emmy blir ensam får Karin möjlighet att hjälpa henne som kommunalt avlönad hemvårdare. Emmy, som är nästan blind och inte kan klara sig själv, överlåter nu sin gård till Karin genom ett gåvobrev, med förbehållet att hon utan vederlag själv ska kunna nyttja bostadshuset så länge hon själv önskar. Emmy har inga egna nära anhöriga, och säger sig tycka mycket om Karin och hennes make. Om dessa

1 Materialet är hämtat från domstols- och förundersökningsprotokoll. Namnen är fingerade. Moderna tider 1992 hade en artikel om dessa fall (Zaremba 1992). Där tolkas de i perspektivet »den förtryckande staten". Materialet tillåter dock många fler perspektiv. 
ägde och skötte gården, skulle Emmy kunna bo kvar i sitt hem. Karin meddelar förhållandet till sin arbetsgivare, kommunens socialförvaltning, som polisanmäler henne och begär förundersökning för misstänkt mutbrott. Hon frikänns emellertid med hänvisning till att hon och grannen varit vänner sedan långt tidigare.

Det andra fallet gäller Lena som var hemvårdare åt Per. Per är ensam och deprimerad sedan hans hustru dött. Han blir förtjust i Lena och får ibland en kram och godnattpuss. Han börjar ge henne pengar. Enligt domstolsprotokollet sade Lena att hon inte fick ta emot några pengar men Per blev så besviken. Hon tog därför pengarna men lade undan dem i ett kuvert, sammanlagt 2750 kronor, fast besluten att lämna tillbaks dem vid lämpligt tillfälle. En gång, när hon själv var helt utan pengar använde hon dock 250 kronor. Så småningom kontaktas hon av en anhörig till Per som fått reda på att Per gett Lena pengar. Lena lämnar då kuvertet med pengarna till den anhöriga. Även Lena blir efter en tid häktad misstänkt för mutbrott. Hon döms som skyldig mot sitt nekande, får villkorlig dom och förväntas förlora sin tjänst vid kommunen. Per får aldrig reda på varför Lena slutade komma²).

\section{Kvinnoforskningen och omsorgsarbetets osynlighet}

De två rättsfallen vill jag tolka med hjälp av begreppen omsorgsmoral och rättvisemoral. Carol Gilligan är en av de kvinnoforskare som är starkast förknippad med dessa begrepp (Gilligan 1985). Hon var från början

2 Zaremba 1992. lärjunge till Kohlberg som arbetade med forskning om barns moraliska utveckling. Han hade konstruerat en 6-gradig skala för att mäta moralisk utveckling. Det visade sig att kvinnorna hade en tendens att fastna på steg 3-4. Skalan var visserligen utvecklad på ett material med enbart pojkar. Kohlberg menade dock att skalan svarade mot ett allmänmänskligt utvecklingsförlopp. Flickorna/kvinnorna skulle kunna komma längre bara de fick utbildning och erfarenhet från "det större samhälletsı frågor. Gilligan ifrågasatte emellertid Kohlbergs förment könsneutrala skala. Hon började i egna studier att noga lyssna på kvinnorna. Ur deras resonemang urskiljde hon ett mönster av ett, som hon kallade omsorgsmoraliskt förhaillningssätt, som aldrig blev synligt med Kohlbergs begreppsapparat.

Gilligan kan ses som exempel på en viktig riktning inom kvinnoforskningen där forskaren försöker lyssna på och tänka sig in i de intervjuades resonemang (Haavind, 1992). Utgångspunkten ska inte vara någon abstrakt föreställning om vad som är rationellt eller moraliskt riktigt som kvinnornas bedömningar mäts mot. Istället är utgångspunkten att deras resonemang bygger på deras erfarenheter och är rationella och moraliskt riktiga utifrån dessa erfarenheter. En bred flora av kvinnoforskning har vuxit fram med denna ansats där begrepp som omsorgsrationalitet, ansvarsrationalitet och omsorgsmoral tagit form (Noddings 1984, Gilligan 1985, Tronto 1987, 1994, Ve 1994, Gunnarsson 1994).

Grundläggande för dessa begrepp är synen på omsorgsarbetets karaktär:

Omsorg är något som uppstår i en relation

Inga Michaeli: Omsorgsarbetet i brytningen... 
mellan (minst två) människor: Den ena (den som ger omsorg) visar bekymmer, omtänksamhet, kärlek, tillgivenhet inför den andra (mottagaren av omsorgen). Den som behöver omsorg är dyrbar för den som ger omsorg, och när den förre lider, lider givaren tillsammans med honom eller henne och sörjer för att smärtan eller obehaget lindras. (Wærness 1983, s. 18).

Omsorgsarbete, enligt Wærness syftar på »icke ömsesidig omsorg" där den ena parten inte kan reda sig på egen hand. Förhållandet mellan parterna i ett omsorgsarbete kan därför inte bygga på likvärdiga ge- och taförhållanden (ibid, s.19). Omsorgsarbete handlar inte om att producera ting eller regler, det handlar om arbete med människor, att stötta livets processer, underlätta växande och lindra lidande och tillbakagång. Omsorg kräver en helhetssyn på människan som både subjekt och objekt (Eliasson 1992). Det är en interaktiv process där lyssnandet, stödjandet, "att bli sedd och bekräftad" är centrala komponenter. Ulla Holm (1993) talar om "modrandet" som en praktik som både män och kvinnor, mödrar och icke mödrar kan utveckla. Hon ser modrandet som praktik ingående i en "underkultur", som ofta är osynlig i »överkulturens« föreställningsvärld vars företrädare har ringa erfarenhet av modrandets praktik.

Gemensamt för dessa tankar är att omsorgsarbete är en praktik med många svåra överväganden, överväganden som ofta är osynliga i överkulturen och där rationalitet och moral är av annan art än i den dominerande överkulturen.

\section{Omsorgsmoral och rättvisemoral}

Gilligan utskiljde och formulerade alltså ett moraliskt förhållningssätt som avvek från det som Kohlbergs skala byggde på. De två förhållningssätten, eller moraliska positionerna, har senare gått under namnen omsorgs- eller ansvarsmoral respektive rättvisemoral. De kan sammanfattas enligt följande (Tronto 1987):

I en rättvisemoralisk position betonas lika rättigheter, att alla ska behandlas lika och efter allmängiltiga principer. Dessa principer kan rangordnas, t.ex. så att det är värre att döda än att stjäla. En moralisk situation karakteriseras av att ett antal rättigheter eller principer står emot varandra. Vad som är rätt att göra i en sådan situation kan i princip härledas fram om man känner till de olika principerna och deras rangordning. Moral är därför i grunden det samma som rationalitet.

I en omsorgsmoralisk position står den konkreta, unika människan i centrum med önskan att bli sedd och bekräftad som den unika person hon är. Vad som är moraliskt riktigt kan inte härledas objektivt ur några generella principer utan beror på kontexten. Moraliska problem kan uttryckas i termer av att jämka mellan självets respektive andras behov, att balansera konkurrens mot samarbete och att upprätthålla den sociala väven av relationer. Att abstrahera till universella principer innebär att ställa sig utanför väven av relationer.

De två positionerna avspeglar två olika bilder av världen, menar Gilligan. I den ena består samhället av en hierarki av lagar, regler och värden där människor är fria, auto- 
noma, opartiska och avskilda. I den andra bilden består världen av nätverk av relationer mellan unika, icke utbytbara människor. Vi växlar mellan dessa två sätt att uppfatta världen, ett växelspel som både män och kvinnor praktiserar, menar Gilligan (ibid s. 8).

\section{Analys av de två fallen}

Rättsfallen åskådliggör de två bilderna av världen, världen som en väv av relationer eller ett system av regler och oberoende, autonoma personer. En gåva, som kan ses som ett tecken på personliga relationer och en kvalitet $\mathrm{i}$ omsorgens perspektiv bedöms nu utifrån rättvisans världsbild. I denna värld uppfattas en gåva till en tjänsteman som en muta i det fall belöningen är otillbörlig. "Otillbörlig är varje gåva till en tjänsteman, om förmånen i fråga eller förväntan att erhålla den kan tänkas påverka tjänsteutövningen eller eljest sätta honom i tacksamhetsskuld till givaren." (Medicinalväsendets författningssamling 1975:41). För att fälla en tjänsteman för mutbrott måste man alltså visa att tjänstemannen givit, eller förväntats ge något i gengäld utöver det som ingår i tjänsteutövningen.

Att Karin och Lena tittat till sina skyddslingar utanför arbetstiden, att Karin gjort upp eld i spisen hos Emmy varje morgon innan hon själv gått till sitt eget jobb, att Lena gett Per godnattpussar, det blir nu något misstänkt. Det blir beviset för muta eftersom det inte ingår i den ordinarie tjänsteutövningen. I rättvisans tankevärld går man inte "och tar reda på skiten« hos en gammal människa utan att få något materiellt i utbyte. Att göra detta av tillfredsställelsen av att se den andra må bra och av att man själv li- der när man vet att den andra far illa - det tycks i rättvisans värld ses som »laster».

\section{Karins fall}

I förundersökningen förhörs grannar och arbetskamrater till Karin. Frågorna handlar om relationen mellan Karin och Emmy och varför Karin gjort dessa tjänster åt Emmy utöver det ordinarie arbetet som hemvårdare.

Först finns de två parternas framställning, Karins och Emmys, där båda är överens; de tycker om varandra säger de. Emmy vill skänka sin gård till Karin och Kalle mot det att hon ska kunna bo kvar där och makarna tar hand om henne. En granne, som också är "god man" till Emmy stöder Karin helt. Han har varit med och bevittnat gåvobrevet när det skrevs under. Han tolkar gåvan i ett självklart omsorgsperspektiv: „Karin har gjort ett jättejobb..... fruktansvärt att Karin ska misstänkas för brott. Hon har ju i stället hjälpt en människa att leva ett drägligt liv, kanske t.o.m. överleva.»

I många av förhörsprotokollen finns dock en misstänksamhet mot Karin ur rättvisans perspektiv. Det är något konstigt att hon gör saker utöver det hon behöver enligt sitt schema: Onödigt att Karin gör saker som sedan ett vårdbiträde kommer för att göra om ett par timmar. Karin »lägger sig i«, "springer där hela tiden", gör andras uppgifter, "har helt tagit över» osv. Förutom misstänksamheten om att det är något annat hon är ute efter, så ses det också som störande att någon av omsorgsmoraliska hänsyn kommer in i den rationellt ordnade omsorgsorganisationen.

Förhörsprotokollen antyder även en misstänksamhet ur ett omsorgsperspektiv. Det 
antyds att Karin missbrukar Emmys beroende av henne. Hon respekterar inte Emmys integritet, förhindrar hennes kontakter med släktingar, stödjer henne inte i att våga operera ögonen. Detta kan ses som omsorgsprofessionella kommentarer om hur man ska göra för stödja den människa man har omsorg om. Karin handlar inte som hon borde om det varit en äkta omsorgsrelation. Hon har inte visat gott omdöme med hänsyn till omsorgsmottagarens maktlöshet och beroende av omsorgsgivaren.

Tre tolkningar av situationen är av intresse. 1. Karin och Emmy är goda vänner och grannar på någorlunda jämnbördig nivå. De har kommit fram till en lösning som är rationell för dem båda. 2. Karin förstår inte att hantera det etiska omsorgsansvaret på ett bra sätt, hon har bristande omsorgsmoralisk kompetens. Hon förstärker därigenom Emmys beroende av henne där överlåtelse av gården blir en logisk följd. 3. En medveten manipulation från Karins sida i syfte att överta gården.

\section{Lenas fall}

För Lenas del har förundersökningsprotokollen ej varit tillgängliga. En viktig fråga som ändå väcks är varför hon inte sade ifrån mer bestämt gentemot Per när han ville ge henne pengar. Ska pengarna ses som muta innebär det att hon fick dem, mot att hon gav Per godnattpussar. Minst lika troligt är dock att hon inte klarade av att säga emot. En äldre herre som blir besviken, kanske arg och tar ton, är det inte alltid så lätt att säga emot, särskilt inte som kvinna. Lena kanske inte förmådde utveckla detta autonoma, distanserade "Jag", som med professionell auktoritet kan tala om vad som gäller. I detta läge behövde hon givetvis dessa regler om gåvor, men också någon som hjälpte henne att klara den egna integriteten. Här finns också tre möjliga tolkningar av Lenas engagemang: 1. En del i en äkta omsorgsrelation. Hon vill inte göra Per besviken. 2. Hon vill lura till sig pengar. Att hon »lånade» pengar ur kuvertet tyder på att hon hade ont om pengar. 3. »Kvinnlig undfallenhet", bristande förmåga att stå på sig.

\section{Rättens bedömning}

Hur bedöms då dessa fall i "rättvisans värld». Karin har uppenbarligen fått en gåva av betydande ekonomiskt värde. Den rättsliga frågan gäller: var det muta eller inte, dvs. var det en otillbörlig belöning? Detta beror i sin tur på om Karin skall uppfattas som i första hand granne och vän eller som vårdbiträde i sin relation till Emmy. Rätten bedömer henne som i första hand granne och vän vilket innebär att hon kan tänkas ha fătt gården av vänskap, inte som otillbörlig belöning. Därmed är gåvan mellan dem att anse som en gåva mellan två rättsliga subjekt, och eftersom båda är överens, så finns det inget mer att tillägga. Formulerat i de tre tolkningarna av Karins fall så är det närmast alternativ 1 som rätten går på, en rationell överenskommelse mellan två autonoma subjekt. Åklagaren utgångspunkt var däremot alternativ 3, Karin har missbrukat sin position som tjänsteman. Den egentliga frågan, huruvida en gammal människas beroende i en omsorgssituation utnyttjades eller inte (oavsett om vårdaren var granne eller offentliganställd), den berördes på så vis inte alls. För Lena finns däremot ingen tveksamhet. Hon har inte känt Per sedan tidigare. Det måste alltså vara som tjänsteman som 
hon tagit emot pengarna, och hon kan, om än omedvetet ha förlett Per att tro att han kan få fortsatta godnattpussar genom att ge henne gåvor. Lena har alltså brutit mot de regler som hon som tjänsteman borde följa.

\section{Diskussion}

Rätten löser alltså dilemmat mellan omsorg och rättvisa genom att bestämma om fallen hör till den privata eller till den offentliga sfären. Det moralfilosofiska och rättsliga problem som ligger inbäddat i välfärdsstatens omsorgsansvar berörs därigenom inte. Genom att hålla sig till denna uppdelning behöver de inte ta ställning till varför Karin respektive Lena gjorde som de gjorde och om relationen vårdare - vårdad var en bra omsorgsrelation eller inte. Omsorgsperspektivet förblir osynligt.

Diskussionen ovan visar också att sett ur en omsorgsmoralisk position, så hade slutsatserna kunnat bli tvärt om. T.ex. att Karin utnyttjade sitt överläge som vårdare. Hon stödde inte Emmy att utveckla sin självständighet utan övertygade henne istället om att ge bort sin gård; att Lena hade tagit emot pengar av Per för att inte göra honom ledsen, något som var riktigt med hänsyn till Pers psykiska behov i den rådande situationen.

Samtidigt visar exemplen hur även rättviseperspektivet är nödvändigt då detta berör maktrelationen mellan de två parterna, mellan vårdare och vårdad. I ett omsorgsperspektiv kan Karin misstänkas för att inte hjälpa Emmy att fatta ett självständigt beslut. I ett rättviseperspektiv handlar det om Emmys rättigheter och hur regler kan stödja hennes rättigheter. Genom "god man"-institutionen och förbud mot gåvor hade man försökt ge Emmys rättigheter en förstärkt position. Lenas fall kan användas för att belysa en tänkbart motsatt relation. Lena kanske behövde stöd i form av regler för gåvor för att kunna "värja sig» mot dem hon hade omsorg om, så att hon inte av snällhet hamnade i en situation där hon blev moraliskt bunden att göra mer än vad hon egentligen ville. Samtidigt får sådana regler inte hindra omsorgens relationer från att utvecklas.

De två rättsfallen synliggör alltså hur rättvisemoralen enbart, dvs. enbart regelföljning, ger en torftig bedömning. Det behövs därför någon form av moralisk position som överskrider motsättningen mellan omsorg och rättvisa. En sådan position ger Sheila Benhabib med den interaktiva universalismen. Jag vill använda mig av hennes modell för att föra diskussion vidare.

\section{Den interaktiva universalismen}

Benhabib föreslår en moralfilosofisk modell för att hantera motsättningen mellan rättvisa och omsorg. Hon knyter denna till en pågående diskussion mellan universalister och kontextualister genom att omformulera rättvisans universalism och omsorgens kontextualism med hjälp av begreppen Den generaliserade andre och Den konkrete andre. ${ }^{3)}$

Utgångspunkten Den generaliserade andre innebär att vi ser varje individ som en rationell varelse med samma rättigheter och skyldigheter som vi skulle vilja tillskriva oss själva. Vi abstraherar bort individualiteten

3 Begreppen är hämtade från Mead, men något omändrade. 
och den konkreta identiteten hos den andre. Det som konstituerar den andres moraliska dignitet är inte vad som skiljer oss åt utan vad vi som talande och handlande rationella varelser har gemensamt. De moraliska kategorierna är rättigheter, skyldigheter och berättiganden och motsvarande moraliska känslor är respekt, plikt och värdighet.

Utgångspunkten Den konkreta andre innebär att vi förväntas se varje rationell varelse som en unik individ med konkret historia, identitet och emotionell konstitution. Här abstraherar vi bort det som konstituerar vår gemensamhet, och fokuserar på det individuella. Vi försöker förstå den andres behov, hans eller hennes motiv och önskningar. De moraliska kategorierna är ansvar, förpliktelse och dela tillsammans. Motsvarande moraliska känslor är kärlek, omsorg, sympati och solidaritet. (Benhabib 1994)

Dessa två utgångspunkter har setts som oförenliga, säger Benhabib. I samtida universalistisk moralteori dominerar synen Den generaliserade andre. Mest känd är kanske Rawls teori och hans "slöja av ovetskap«. Poängen är att moraliska bedömningar ska göras som om man inte hade kunskap om egna eller andras intresse i frågan. Men, invänder Benhabib, „tvärt emot Rawls egna intentioner kan "slöjan av ovetskap" tillåta alla våra missförstånd och fientligheter $\mathrm{i}$ samhället att förbli som de är, gömda bakom en slöjau. I motsats till Rawls menar hon att bara en moralisk dialog som är sant öppen och reflexiv kan leda till ömsesidig förståelse av den andra (ibid s. 189).

I dag kritiseras den universalistiska moralfilosofin av ett flertal olika tänkare som tar sin utgångspunkt i Den konkrete andre (t.ex. Walzer, Sandels, MacIntyre, Taylor).
Denna riktning kritiseras i sin tur för att vara konserverande och att den kan bli egoistisk där man bara ser till den egna gruppens intressen. Benhabib vill därför ha en modell som rymmer "både / och". Hon vill ha ett moraliskt system vars utgångspunkt är Den konkreta andra som respekteras som unik och annorlunda. Men hon vill ha universalistmoralen som den som sätter gränser (ibid s. $191 \mathrm{ff}$ ).

Universalism innebär dock inte att formulera allmängiltiga principer, säger Benhabib. Avgörande för universalismen inom etiken är istället natt vi handlar så att vi respekterar värdigheten och värdet hos alla de inblandade och att vi är villiga att göra upp i kontroversiella frågor genom öppen och obegränsad diskussion med allaw. I stället för allmängiltiga principer vill hon se en procedur där alla berörda kan komma till tals och bli sedda. Hennes förslag är en interaktiv universalism där Den generaliserade andre respekteras genom proceduren där alla kommer till tals och där Den konkrete andre, som framträder i denna procedur respekteras som unik och därmed olik.

\section{Tillämpning på de två fallen}

Hur skulle då Benhabibs modell te sig i en praktisk tillämpning? Skulle hennes modell kunna ge en mer nyanserad bedömning av de två rättsfallen?

I fallet med vårdbiträdet Karin som fick Emmys gård som gåva, blev Karin frikänd då rätten menade att hon fått gåvan som vän och granne. Den viktiga frågan ur ett omsorgsperspektiv hade dock inget att göra med om Karin uppträdde som vän eller tjänsteman. Den gällde istället frågan om 
Karin hade missbrukat sitt överläge i omsorgsrelationen eller inte. En sådan bedömning gjordes men endast i en mycket snäv mening av rätten.

Här skulle Benhabibs interaktiva universalism innebära strängare krav: Hade Karin verkligen tänkt sig in i Emmys situation, hade hon verkligen lyssnat till henne, var det säkert att inte Karins önskan watt ta hand om» gjort Emmy till ett objekt för omhändertagande. Var verkligen den tänkta lösningen den bästa för Emmy, där Emmy skulle bo i kammaren och de själva flytta in i huset. Det är först om Karin kunde göra troligt att hon faktiskt hade tänkt sig in i dessa olika situationer och talat med Emmy om olika lösningar och olika juridiska former för detta, som Karins förfarande kunde erkännas som moraliskt rättfärdigt.

För Lena var situationen den omvända. Hon blev fälld för att hon som tjänsteman inte hade följt reglerna. Med den interaktiva universalismen skulle Lenas fall inte ha behövt få denna utgång. Utifrån en sådan moralisk posistion borde Lena ha tänkt igenom hur Per uppfattade situationen: Var gåvan viktig för honom som uttryck för kärlek; eller var han senil och förvirrad och rädd för att bli övergiven där gåvan var en vädjan; eller ville han köpa kärlek? Kanske var gåvan ett försök från hans sida att återupprätta sin egen värdighet, att inte bara vara den som tar emot? Vad tyckte hon själv om att ta emot gåvan: Var den generande; hade hon kanske behov och glädje av den och kunde ta emot den med tacksamhet; eller kunde gåvan ge Per felaktiga förväntningar om en relation som inte var ömsesidig; kanske behövde hon värna om en distans som Per ville riva ner med hjälp av gåvan? Vilka fler be- rördes av Pers gåva? Vad tyckte hans släktingar? osv.

Om Lena, t.ex. i samtal med sin arbetsledare hade kunnat utveckla detta resonemang och därmed visa hur hon tänkt sig in i de andra parternas situation, bekymrat sig om dem, hört deras åsikter osv. - så hade hennes handlande kanske kunnat rättfärdigas utifrån Benhabibs modell.

\section{Offentliggörandet}

Med en modell som Benhabibs borde det alltså gå att föra mer nyanserade resonemang kring de två fallen där både generalitet och kontextuell anpassning ges utrymme. Men det handlar inte bara om att rättfärdiga omsorgsgivarnas överväganden inför dem själva. Det handlar i än högre grad om att ge deras överväganden legitimitet, vilket kräver att dessa överväganden kan »offentliggöras", dvs. diskuteras offentligt som relevanta och viktiga problem inom omsorgsarbetet.

Frågan om vad som kan och bör diskuteras offentligt är viktig för Benhabib. „Vi måste förståu, säger hon, "varför kvinnornas och omsorgens röst har varit så marginaliserad i moralteorin och hur det moraliska autonomiidealet och definitionen av den moraliska sfären fortsätter att tysta kvinnornas röster» (ibid s. 193). Uppdelningen i offentligt och privat i form av "rättvisans« respektive "det goda livetsu domän avspeglar drag $i$ vår kultur "som förvränger vår människosyn«. I en debatt med Habermas menar hon att Gilligans arbete innebär en utmaning för moralteorin som Habermas inte har tagit på allvar (ibid s. 201).

Hur ska vi förstå detta? Vari ligger skill- 
naden mellan Benhabibs och Habermas synsätt? Vad är det som tystas? Och vad innebär Benhabibs förslag i en konkret tillämpning? Här vill jag använda Lenas fall för att komma en bit på väg.

Den brännande frågan för mig när det gäller Lena är: Varför stod inte Lena på sig gentemot Per om att hon inte fick ta emot några pengar? Enligt domstolsprotokollet tackade Lena först nej till gåvan, sa att hon inte fick ta emot pengar. Per blev besviken, sa att ingen behövde få reda på något. Han insisterade, blev först arg och sedan sårad ${ }^{4}$. Ville hon egentligen ha pengarna och lät sig därför övertalas? Men hon använde ju aldrig pengarna och hon lämnade tillbaks dem direkt när den anhöriga frågade efter dem. Hade hon velat lura till sig dem skulle hon ju låtit pengarna försvinna och helt neka till att hon fått dem. Var det av genuin omsorg om Per, att inte göra honom ledsen? Eller hade hon svårt att säga emot honom och driva igenom sin egen vilja? Kunde hon inte värja sig mot "den traditionella kvinnlighetens" påbud att vara till lags. Varför respekterade Per inte hennes »Nej« som ett allvarligt menat "Nej»? Och sedan, när frågan kommer upp i offentligheten så är det hon som blir dömd för att hon inte sa »Nej på riktigt (").

Detta för vidare till frågan om offentliggörande. Om det nu var så att Lena inte klarade av att stå på sig, varför gick hon då inte

4 Enligt Zaremba 1992.

5 Detta anspelar på Patemans diskussion kring mäns uppfattning om kvinnors samtycke, hämtat från bl.a. rättegångar om våldtäkt och citat från Rousseau. En kvinnas heder gör att hon inte kan tacka ja till sexuella inviter, säven om hon egentligen önskar dem. »En kvinnas Nej är därför inte ett riktigt Nej». (Pateman, 1980). till sin arbetsgivare och sa att det här klarar jag inte, han är för stark och tar över? Ett skäl skulle kunna vara att hon inte vågade, hon visste att hon gjort något som var mot reglerna och dessutom är det pinsamt att medge att man inte klarar av att sätta gränser, inte klarar jobbet.

Exemplet med Lena kan tolkas med begreppen »över-« och "underkulturer" som Ulla Holm tagit upp (se ovan). Man kan alltså tänka sig att det finns ideal och regler om hur man ska vara som opartisk tjänsteman som kan strida mot omsorgens och "modrandets" praktik. Samtidigt förväntas i vårt samhälle att den som ger omsorg följer omsorgens logik i den mån detta krävs för att man ska kunna göra ett bra jobb. Men den som gör det fördöms, om hon i en konflikt skulle bli ertappad med att bryta mot rättvisans logik. För att kunna och våga offentliggöra överväganden gjorda i ett omsorgsperspektiv - t.ex. gå till sin arbetsgivare och diskutera sina problem och hävda det riktiga i att följa omsorgens logik - så måste det alltså utvecklas en moralisk position där ens handlingar inte fördöms definitionsmässigt och på förhand därför att rättvisemoralen alltid har företräde.

Offentliggörande av omsorgens överväganden inom välfärdsstatens ram är alltså inte något självklart. Kan detta vara en orsak till att omsorgsarbetet är så osynligt och lågt värderat i vårt samhälle? Benhabib menar det.

\section{Vad får ingå i den offentliga diskursen?}

Att Lena kanske inte vågade berätta för sin chef om sitt dilemma reser alltså frågan om vad som kan offentliggöras. Debatten mel- 
lan Habermas och Benhabib om Gilligans arbete belyser detta. (Benhabib 1994, Habermas 1990a, 1990b, Michaeli 1995) ${ }^{6}$.

Problemet för universalisterna har gällt hur de universella reglerna och normerna ska bestämmas. Kant tänkte sig att de fanns i sig och med förnuftets hjälp kunde människan/mannen tänka ut dem. Rawls tänkte sig att bakom "slöjan av ovetskap" så kunde moraliska normer konstrueras fram. Habermas och Benhabib däremot tänker sig att i den etiska diskursen så ska de deltagandes intressen och värderingar komma till uttryck. Habermas intar en universalistisk position som bygger på att gemensamma normer arbetas fram i en "diskursiv process». Till moraliska frågor räknar han därför bara sådana där man kan hoppas på att nå konsensus och kunna enas om generella principer, dvs. »sådana frågor där den moraliska grunden är någon form av rättvisau (Habermas 1990b p.95-96). Övriga frågor hör till "ego-utvecklingen" och ska bedömas utifrån individens eller gruppens sociala och kulturella sammanhang. De hör till »det goda livet» (här ungefär lika med det privata) och berörs inte av den offentliga diskursen.

Benhabib invänder dock att Habermas har fastnat i en formalistisk syn som inriktar sig på principer och att han gör en onödigt strikt uppdelning mellan "rättvisans domän" och "det goda livet» (Benhabib 1994, p. 29 ff). Det är inte principerna som moraliskt berättigar ett visst handlande. Det bestäms i stället av diskursen i sig, att den tagit form som en procedur som uppfyller vissa kriterier. För Benhabib är förebil-

6 Nedanstående analys finns mer utvecklad i Michaeli 1995. den moralsamtalet, där målet för samtalet inte är konsensus och samtycke utan »kommunikation med den andra som jag vet att jag i slutänden måste komma överens med" (Ibid, p.25).

Hur kan då dessa idéer knytas till Lenas fall? Som jag tolkar Habermas så kan Lenas handlande antingen bedömas direkt utifrån reglerna om gåvor i tjänsten, som i princip är baserade på rättviseprinciper framtagna $\mathrm{i}$ en diskursiv process. Utifrån en sådan bedömning har hon gjort fel. Eller så kan man se hennes överväganden som en tillämpning av olika principer. Hur moraliska principer tillämpas hör dock till »det goda livet", anser Habermas (Habermas 1990b, s 96 ff). Om hon ska följa regler baserade på rättviseprinciper eller följa omsorgens påbud det är inget som man kan diskutera sig fram till och enas om i en offentlig diskurs. Det hör därför enligt Habermas modell till det privata. Därmed osynliggörs Lenas vånda.

I motsats till Habermas vill Benhabib se en moralteori där frågor om "det goda livet» flyttas in mot diskursens centrum. De ska inte stängas in i det privata (i meningen det dolda). Gränserna för moraldiskussionen ska flyttas så att "visioner om det goda livet som ligger bakom uppfattningar om rättvisa och antaganden om behov och intressen som ger stöd åt rättighetsanspråk, blir synliga.ı (ibid, s. 192). De diskussioner som Lena skulle tänkas kunna föra med Per, hans anhöriga, sin arbetsledare och sig själv utifrån Benhabibs interaktiva universalism, de skulle alltså föras upp i en offentlig diskurs som något av vikt ${ }^{7}$.

7 Detta är inte detsamma som att de berördas situation utlämnas för offentligt beskådande, att 
Benhabibs resonemang pekar alltså mot att den dominerande moralfilosofin kan vara en orsak till att omsorgens och kvinnornas arbete hållits dolt och tystas. I den dominerande moralfilosofin, är det bara frågor där man kan räkna med att enas, som kan diskuteras i den offentliga sfären. Problemet med omsorgsmoralen ur den dominerande teorins perspektiv är att det inte finns något "rätt» eller "fel" med hänvisning till generella regler, allt beror på kontexten. Frågor och överväganden $\mathrm{i}$ ett omsorgsmoraliskt perspektiv förs därför sällan upp i det offentliga. Följden blir därför att många av omsorgsarbetets överväganden förvisas till det privata, till det dolda.

\section{Avslutning}

I dag ser vi en hur gränsen mellan privat och offentligt omvandlas och uppluckras. Omsorg med dess inriktning på den unika människan, på relationen och sammanhanget bryts mot det offentligas rättvisa. De två rättsfallen belyser detta. Fallens rättsliga hantering innebar att de hänfördes till antingen det privata eller det offentliga. Detta innebar att överväganden knutna till omsorgsmoralen osynliggjordes.

För att kunna hantera dagens diffusa gräns mellan privat och offentligt behövs en moralfilosofisk position som överskrider motsättningen mellan omsorgsmoral och rättvisemoral. Benhabib tillhandahåller en sådan. Med hennes modell kan de två fallen diskuteras mer nyanserat, där både kontex-

deras integritet undergrävs. Diskussionen kan föras principiellt för att lära av de enskilda fallen, man kan använda fingerade namn osv. tuella och generella överväganden ryms. En viktig effekt blir möjligheten till »offentliggörande«. Frågor som rör omsorgen och omsorgsarbetet kan med Benhabibs synsätt lyftas fram i offentlighetens ljus och belysas i sin komplexitet. Handlingens rättfärdighet bedöms utifrån andra grunder än att reglerna följs.

Varför är det då så viktigt att ge omsorgens överväganden offentlighet? Här är tre skäl, säkert finns det fler.

- För att synliggöra omsorgsutövarnas och de omsorgsberoendes villkor, omsorgsarbetet som process och dess överväganden. Att peka på orättvisor när det är för få som tar ansvar för det tunga arbetet. Att lyfta fram vad som ger tillfredsställelsen i omsorgsarbetet, förutsättningar för och nödvändigheten av denna tillfredsställelse för att människor ska orka ägna sig åt tungt omsorgsarbete. "Effektiviseringar" som görs utan sådan kunskap kan bli förödande.

- För att rättfärdiga omsorgens överväganden och synliggöra dess kompetenser. Omsorgsmoralens avvägning mellan att bry sig om andra och vara sann mot sig själv, måste respekteras som en vuxen människas mogna överväganden. Förhållningssätt som går ut på att lyhört invänta, samtal som bekräftar och stöttar måste kunna erkännas som som utslag av erfarenhet, insikt och praktiskt handlag, inte avfärdas som »kvinnligu förvirring, omogenhet eller svårighet att fatta beslut.

- För att genom offentliga diskussioner och utbyte av erfarenheter bidra till ego-utvecklingen hos de berörda och till att utveckla den psykologiska kunskap som bl.a. Gilligan menar är nödvändig för att 
hantera omsorgens grundläggande dilemma - avvägningen mellan själv och andra.

Dolda kvinnliga offentligheter har funnits i alla tider: mötet vid brunnen, syjuntan och i dag fikarasten och mötet i dagistamburen (Waldén 1997). Tidningsspalter, romaner och samtal inom religiösa samfund kan vara andra sådana offentligheter. Men dessa samtal har inte erkänts i den dominerande kulturen som något av vikt. Kanske finns det dock ansatser till mer erkända och öppna »offentliga rum» i dag. Handledarfunktionen inom socialtjänsten skulle kun- na vara en sådan, där arbetsledaren eller en opartisk person för regelbundna samtal med personalen om de problem de upplever i sitt arbete. En annan ansats kan vara försöken att utveckla FoU-centra där forskare tillsammans med de berörda, personal, klienter och anhöriga diskuterar och försöker sätta ord på det arbete och de överväganden som dagligen måste göras.

Nya "offentliga rum» behöver uppfinnas för sådana samtal. Kvinnorörelsena gamla slogan: „Det personliga är politiskt» kanske ska aktualiseras igen, men nu som motto för "omsorgsrörelsen".

\section{Summary \\ Care work in the confrontation between private and public}

The welfare state with care organized by the public sector has blurred the border between private and public with their different types of value system. The ethics of care is confronting the ethics of justice. Today new forms of state-organized care are turning up: medical experts are treating elderly at home, companies for caring are appearing on the market, voluntary organizations are encouraged by the state to take part in caring. This developement is creating new types of borders between private and public and new types of problems.
Two cases are discussed in which two home helpers had received gifts from their clients and were brought to court for taking briebes. The cases can be understod as a clash between the two value systems. A moral position presented by Sheila Benhabib which would override the contradiction between care and justice and thus allow a moral discussion and a deeper understanding of the cases. Such a position could justify the consideration of the home helpers and thus give an opportunity to discuss the cases in public. 


\section{Litteratur}

Benhabib, S. (1994) Autonomi och gemenskap. Kommunikativ etik, feminism och postmodernism, Daidalos. Engelsk utgåva 1992, Situating the Self. Gender, Community and Postmodernism in Contemporary Ethics. Polity Press.

Eliasson, R. (1992) „Om synen på kunskap i förhållandet teori-praktik" i Eliasson, R., red,: Egenheter och allmänheter. Lund: Studentlitteratur.

Gilligan C. (1985) Med kvinnors röst, Prisma.

Gunnarsson, E. (1994) Att våga väga jämt! Om kvalifikationer och kvinnliga förhållningssätti ett tekniskt industriarbete. Luleå:Tekniska högskolan i Luleå.

Habermas, J. (1990a), Moral Consciousness and Communicative Action, The MIT Press, Cambridge, Mass.

(1990b)/Nielsen, Jurgen Habermas: „Morality, Society and Ethics. An interview with Torben Hviid Nielsen", Acta Sociologica 1990 (33), 2:93114

Haavind H. (1992) „Vi måste söka efter könets förändrade betydelse». Kvinnovetenskaplig tidskrift 1992:3

Holm, U. (1993) Modrande och praxis. En feministfilosofisk undersökning. Göteborg: Institutionen för filosofi, Göteborgs universitet.

Johansson, L. (1997) "Anhöriga och frivilliga - lösningen på äldreomsorgens problem? « i Jennerbert \& Lagercrantz, red,: Äldrepolitik iföränd- ring. Välfärdsprojektets skriftserie nr 9. Stockholm: Nordstedts.

Michaeli, I. (1995) Omsorg och Rättvisa- ett dilemma. Gävle:Meyers.

Noddings N.(1984) Caring. A feminine Approach To Ethics and Moral Education. Univ of Carlifornia press.

Pateman, C. (1980) "WOMEN AND CONSENT", Political Theory, vol 8, No2, May 1980, p. 149168.

Szebehely, M. (1998)»Hustruns hjälp eller hemtjänstens?" i Äldreomsorgens vardag. En konferens i Göteborg 21-22 april 1998, Stockholm: SFR

Tronto, J. (1987) „Beyond Gender Difference to a Theory of Care", SIGNS, vol 2, 1987

Tronto, J. (1994) Moral bounderies. A Political Argument for an Ethic of Care. London: Routledge Ve, H. (1994) "Gender differences in rationality. The concept of praxis, knowledge and future trends» i Gunnarsson E., Troyer L. red,: Feminist voices on gender tecnology and ethics. Luleå: Luleå university of technology.

Waldén, L. (1997) »Vad konstituerar maktlöshet? läsövning i textilens text.«i Mot halva makten. SOU 1997:113

Wærness, K. (1983) Kvinnor och omsorgsarbete, Prisma

Zaremba M. (1992) „Den obarmhärtige samariten.» Moderna tider 1992, häfte 18 